Journal of Bangladesh Chemical Society, Vol. 24(2), 106-114, 2011.

DOI:10.3329/jbcs.v24i2.9699

\title{
INTERACTIONS OF GUANINE WITH Cr(VI), Ag(I), Cd(II) AND Hg(II) IN ACIDIC AQUEOUS MEDIUM
}

\author{
A. A. SHAIKH, DILIP K. PAUL, M. S. RAHMAN AND PRADIP K. BAKSHI ${ }^{*}$
}

Department of Chemistry, University of Dhaka, Dhaka 1000, Bangladesh

\begin{abstract}
Guanine forms compounds with $\mathrm{Cr}(\mathrm{VI}), \mathrm{Ag}(\mathrm{I}), \mathrm{Cd}(\mathrm{II})$ and $\mathrm{Hg}(\mathrm{II})$ in acidic aqueous media. The compounds are formulated as $\left(\mathrm{C}_{5} \mathrm{H}_{6} \mathrm{~N}_{5} \mathrm{O}\right)_{2}\left(\mathrm{Cr}_{2} \mathrm{O}_{7}\right) \cdot \mathrm{H}_{2} \mathrm{O}$, $\left[\mathrm{Ag}\left\{\left(\mathrm{C}_{5} \mathrm{H}_{6} \mathrm{~N}_{5} \mathrm{O}\right)\left(\mathrm{NO}_{3}\right)\right\}_{2}\right]\left(\mathrm{C}_{5} \mathrm{H}_{6} \mathrm{~N}_{5} \mathrm{O}\right)\left(\mathrm{NO}_{3}\right)_{2}, \quad\left[\left(\mathrm{C}_{5} \mathrm{H}_{4} \mathrm{~N}_{5} \mathrm{O}\right)_{2} \mathrm{Cd}\right]\left(\mathrm{C}_{5} \mathrm{H}_{6} \mathrm{~N}_{5} \mathrm{O}\right) \mathrm{Cl}$ and $\left[\left(\mathrm{C}_{5} \mathrm{H}_{4} \mathrm{~N}_{5} \mathrm{O}\right)_{2} \mathrm{Hg}\right]\left(\mathrm{C}_{5} \mathrm{H}_{6} \mathrm{~N}_{5} \mathrm{O}\right) \mathrm{Cl}$ on the basis of their metal and chloride contents. Physico-chemical properties such as solubility, melting point, IR and UV-visible spectra, magnetic susceptibility, and thermal behavior of the compounds were studied. The composition of $\left(\mathrm{C}_{5} \mathrm{H}_{6} \mathrm{~N}_{5} \mathrm{O}\right)_{2}\left(\mathrm{Cr}_{2} \mathrm{O}_{7}\right) \cdot \mathrm{H}_{2} \mathrm{O}$ was also investigated by continuous variation method.
\end{abstract}

Keywords: Nucleic acids, Guaninium ions, Pyrimidine ring, Magnetic susceptibilities.

\section{Introduction}

Coordination complexes of transition metals have been extensively studied for their antimicrobial $^{1-3}$, cytotoxic ${ }^{4-9}$, and antitumor properties. Complex formation between metal ions and bioligands such as nucleobases or nucleotides may serve as models for metalenzyme reactions in biological systems. Guanine is one of the five main nucleobases found in the nucleic acids, DNA and RNA. It consists of a fused pyrimidine-imidazole ring system with conjugated double bonds. In acidic medium, ring nitrogen $\mathrm{N}(3)$ of guanine is protonated (Scheme 1).<smiles>CC1=C(N)NC(=O)C2N=CNC12</smiles>

Scheme 1. Protonated structure of guanine.

The guanine complexes of several metal ions, such as $\mathrm{Al}(\mathrm{III}), \mathrm{Co}(\mathrm{II}), \mathrm{Cu}(\mathrm{II}), \mathrm{Zn}$ (II), $\mathrm{Pt}(\mathrm{II})$, and $\mathrm{Pd}(\mathrm{II})$ have been reported earlier ${ }^{1,3,4,8}$. It is found from the literature ${ }^{10-16}$ that guanine binds with metal ions through carbonyl oxygen $\mathrm{O}(6)$ and/or imidazolyl nitrogen, $\mathrm{N}(7)$. Early transition metal ions show a preference for the $\mathrm{O}(6)$ position, while later ones prefer $\mathrm{N}(7)$. However, the information available in this regard is very limited to

*Author for correspondences; email: pkb4321@yahoo.ca 
understand the potential binding sites of guanine and the possible mechanism of interaction between guanine and the various metal ions.

\section{Experimental}

Materials

Guanine $\left(\mathrm{C}_{5} \mathrm{H}_{5} \mathrm{~N}_{5} \mathrm{O}\right)$ was purchased from China and used as received. Analytical grade hydrochloric acid and nitric acid (from $\mathrm{BDH}$, England) were used. Silver nitrate $\left(\mathrm{AgNO}_{3}\right)$, cadmium chloride $\left(\mathrm{CdCl}_{2} \cdot \mathrm{H}_{2} \mathrm{O}\right)$ and mercuric chloride $\left(\mathrm{HgCl}_{2}\right)$ were $\mathrm{BDH}$ product. Potassium dichromate $\left(\mathrm{K}_{2} \mathrm{Cr}_{2} \mathrm{O}_{7}\right)$ used in this experiment was collected from Aldrich Chemical Company, USA. Solvents such as methanol, ethanol, and acetone were purchased from Aldrich Chemical Company, USA.

\section{Physical measurements}

Melting points were recorded on a SMP11 electrothermal melting point apparatus and were uncorrected. Spectra of the compounds were recorded as $\mathrm{KBr}$ dices on a Shimadzu (IR-470) (FTIR) spectrophotometer. The UV-visible spectra were recorded on a Shimadzu-160A, Uv-visible spectrophotometer using water as a solvent. Magnetic susceptibility measurement was done by the Sherwood Scientific Magnetic Susceptibility Balance, (Magway MSB MK1). The quasi-static thermogravimetric analysis (QSTG) was carried out in a Carbolite calibrated muffle furnace (CWF 11/5).

\section{Preparation of compounds \\ (i) $\left(\mathrm{C}_{5} \mathrm{H}_{6} \mathrm{~N}_{5} \mathrm{O}\right)_{2}\left(\mathrm{Cr}_{2} \mathrm{O}_{7}\right) \cdot \mathrm{H}_{2} \mathrm{O}$}

Guanine $(0.1501 \mathrm{~g}, 1 \mathrm{mmol})$ was added in distilled water $(20 \mathrm{~mL})$ and to it $4.3 \mathrm{~mL} 1 \mathrm{M}$ hydrochloric acid was added. It was heated on a water bath for evaporation of excess acid. An aqueous solution of $\mathrm{K}_{2} \mathrm{Cr}_{2} \mathrm{O}_{7}(0.2896 \mathrm{~g}$ in $20 \mathrm{~mL})$ was added to it. The resulting mixture was further heated on a water bath until the volume reduced to $10 \mathrm{~mL}$. Yellow granular crystals were obtained after 24 hours at ambient temperature. The crystals were filtered, washed with methanol and dried over silica gel in a desiccator. The compound is soluble in methanol and hexane but slightly soluble in water, ethanol and acetone. The colour of the crystals gradually becomes dirty yellow on exposure to light at ambient temperature.

\section{(ii) $\left[\mathrm{Ag}\left\{\left(\mathrm{C}_{5} \mathrm{H}_{6} \mathrm{~N}_{5} \mathrm{O}\right)\left(\mathrm{NO}_{3}\right)\right\}_{2}\right]\left(\mathrm{C}_{5} \mathrm{H}_{6} \mathrm{~N}_{5} \mathrm{O}\right)\left(\mathrm{NO}_{3}\right)_{2}$}

Guanine $(0.4530 \mathrm{~g}, 3 \mathrm{mmol})$ was added in distilled water $(60 \mathrm{~mL})$ and to it few drops of concentrated $\mathrm{HNO}_{3}$ were added with constant stirring on a water bath. The excess $\mathrm{HNO}_{3}$ was evaporated and then an aqueous solution of $\mathrm{AgNO}_{3}(0.4939 \mathrm{~g}$ in $20 \mathrm{~mL})$ was added. Yellowish crystalline product was started to appear immediately. The beaker was covered with a carbon paper and kept in a dark place at room temperature for complete crystallization. The yellow product was filtered, washed with methanol and dried over silica gel in a desiccator. It is sparingly soluble in hot water but insoluble in cold water, 
methanol, ethanol, acetone and n-hexane. The colour of the compound becomes black on long exposure to light at ambient temperature.

\section{(iii) $\left[\mathrm{Cd}\left(\mathrm{C}_{5} \mathrm{H}_{4} \mathrm{~N}_{5} \mathrm{O}\right)_{2}\right]\left(\mathrm{C}_{5} \mathrm{H}_{6} \mathrm{~N}_{5} \mathrm{O}\right) \mathrm{Cl}$}

Guanine (0.3024 g, $2 \mathrm{mmol}$ ) was dissolved in hot dilute hydrochloric acid (45 mL). After filtration, the solution was heated on a water bath for evaporation of excess acid. An aqueous solution of $\mathrm{CdCl}_{2} \cdot \mathrm{H}_{2} \mathrm{O}(0.4144 \mathrm{~g}$ in $40 \mathrm{~mL})$ was added to the solution of guanine. The resulting mixture was heated on a water bath until the volume reduced to $20 \mathrm{~mL}$. It was allowed to stand at room temperature for crystallization. White shiny needle shaped crystals were formed after 24 hours. The product was separated by filtration, washed with methanol and dried in air and then over silica gel. The compound is slightly soluble in hot water, methanol and ethanol but insoluble in cold water, acetone and hexane. It is quite stable in air.

\section{(iv) $\left[\mathrm{Hg}\left(\mathrm{C}_{5} \mathrm{H}_{4} \mathrm{~N}_{5} \mathrm{O}\right)_{2}\right]\left(\mathrm{C}_{5} \mathrm{H}_{6} \mathrm{~N}_{5} \mathrm{O}\right) \mathrm{Cl}$}

Guanine $(0.4468 \mathrm{~g}, 3 \mathrm{mmol})$ was added in distilled water $(60 \mathrm{~mL}) .12 .60 \mathrm{~mL} 1 \mathrm{M}$ hydrochloric acid was added to it and heated on a water bath. The solution was filtered to remove undissolved residue and heated again to evaporate excess acid. To it an aqueous solution of $\mathrm{HgCl}_{2}(0.8079 \mathrm{~g}$ in $60 \mathrm{~mL})$ was added and stirred. The resulting mixture was concentrated to $20 \mathrm{~mL}$ and kept at room temperature for crystallization. White fluffy crystals were formed after 24 hours. The product was separated by filtration, washed with methanol and dried in air and then over silica gel. The compound is sparingly soluble in hot water but insoluble in cold water, methanol, ethanol, acetone and hexane. It is air stable.

\section{Results and Discussion}

The empirical formulae of the compounds have been established on the basis of their metal and chloride contents analyses. Their physical properties viz. yield, colour, melting point have been studied, and are tabulated in Table 1.

Table 1. Metal and chloride contents and some physical properties of prepared compounds.

\begin{tabular}{|l|c|c|c|c|c|}
\hline \multicolumn{1}{|c|}{ Compound } & $\begin{array}{c}\text { Metal, } \\
\%\end{array}$ & $\begin{array}{c}\text { Chloride, } \\
\%\end{array}$ & $\begin{array}{c}\text { Yield, } \\
\%\end{array}$ & Color & $\begin{array}{c}\text { Melting } \\
\text { point, } \\
{ }^{\circ} \mathrm{C}\end{array}$ \\
\hline$\left(\mathrm{C}_{5} \mathrm{H}_{6} \mathrm{~N}_{5} \mathrm{O}\right)_{2}\left(\mathrm{Cr}_{2} \mathrm{O}_{7}\right) \cdot \mathrm{H}_{2} \mathrm{O}$ & $\begin{array}{c}19.07 \\
(18.05)\end{array}$ & - & 77.79 & Yellow & $180(\mathrm{~d})$ \\
\hline$\left[\mathrm{Ag}\left\{\left(\mathrm{C}_{5} \mathrm{H}_{6} \mathrm{~N}_{5} \mathrm{O}\right)\left(\mathrm{NO}_{3}\right)\right\}_{2}\right]\left(\mathrm{C}_{5} \mathrm{H}_{6} \mathrm{~N}_{5} \mathrm{O}\right)\left(\mathrm{NO}_{3}\right)_{2}$ & $\begin{array}{c}13.33 \\
(12.50)\end{array}$ & - & 71.93 & Yellow & $250(\mathrm{~d})$ \\
\hline$\left[\mathrm{Cd}\left(\mathrm{C}_{5} \mathrm{H}_{4} \mathrm{~N}_{5} \mathrm{O}\right)_{2}\right]\left(\mathrm{C}_{5} \mathrm{H}_{6} \mathrm{~N}_{5} \mathrm{O}\right) \mathrm{Cl}$ & $\begin{array}{c}18.66 \\
(18.60)\end{array}$ & $\begin{array}{c}5.89 \\
(6.03)\end{array}$ & 50.60 & White & $320(\mathrm{~d})$ \\
\hline$\left[\mathrm{Hg}\left(\mathrm{C}_{5} \mathrm{H}_{4} \mathrm{~N}_{5} \mathrm{O}\right)_{2}\right]\left(\mathrm{C}_{5} \mathrm{H}_{6} \mathrm{~N}_{5} \mathrm{O}\right) \mathrm{Cl}$ & 29.05 & 5.13 & 61.93 & White & $250(\mathrm{~d})$ \\
\hline
\end{tabular}


Calculated values of metal and chloride contents are given in parentheses.

IR spectral analyses: Tentative assignments of some important IR bands of the studied compounds were done on the basis of standard references and those of the guanine nucleobase are listed in Table 2 .

Table 2. Tentative IR bands of guanine and metal-guanine compounds.

\begin{tabular}{|c|c|c|c|c|c|}
\hline Compounds & $\begin{array}{l}\mathrm{v}(\mathrm{O}-\mathrm{H}) \text { and } / \mathrm{or} \\
\mathrm{v}(\mathrm{N}-\mathrm{H}) / \\
v(\mathrm{C}-\mathrm{H})_{\text {arom }} \mathrm{cm}^{-1}\end{array}$ & $\begin{array}{c}u(>C=O \\
c^{-1}\end{array}$ & $\begin{array}{c}\delta\left(\mathrm{N}^{+}-\right. \\
\mathrm{H}) \\
\mathrm{cm}^{-1}\end{array}$ & $\begin{array}{c}\mathrm{v}\left(\mathrm{C}-\mathrm{N}^{-}\right) \\
\mathrm{cm}^{-1}\end{array}$ & $\begin{array}{c}\mathrm{v}\left(\mathrm{NO}_{3}{ }^{-}\right) \\
\mathrm{cm}^{-1}\end{array}$ \\
\hline $\mathrm{C}_{5} \mathrm{H}_{5} \mathrm{~N}_{5} \mathrm{O}$ & $\begin{array}{l}3321 \mathrm{~m}, \\
3118 \mathrm{~m}\end{array}$ & $1696 \mathrm{~s}$ & & & \\
\hline$\left(\mathrm{C}_{5} \mathrm{H}_{6} \mathrm{~N}_{5} \mathrm{O}\right)_{2}\left(\mathrm{Cr}_{2} \mathrm{O}_{7}\right) \cdot \mathrm{H}_{2} \mathrm{O}$ & $3640-2700 \mathrm{mb}$ & $1720 \mathrm{~m}$ & $1540 \mathrm{~m}$ & - & \\
\hline $\begin{array}{l}{\left[\mathrm{Ag}\left\{\left(\mathrm{C}_{5} \mathrm{H}_{6} \mathrm{~N}_{5} \mathrm{O}\right)\left(\mathrm{NO}_{3}\right)\right\}_{2}\right]} \\
\left(\mathrm{C}_{5} \mathrm{H}_{6} \mathrm{~N}_{5} \mathrm{O}\right)\left(\mathrm{NO}_{3}\right)_{2}\end{array}$ & $3600-2700 \mathrm{mb}$ & $1680 \mathrm{sb}$ & $1540 \mathrm{~m}$ & - & $\begin{array}{c}1460 \\
\mathrm{mb}\end{array}$ \\
\hline$\left[\mathrm{Cd}\left(\mathrm{C}_{5} \mathrm{H}_{4} \mathrm{~N}_{5} \mathrm{O}\right)_{2}\right]\left(\mathrm{C}_{5} \mathrm{H}_{6} \mathrm{~N}_{5} \mathrm{O}\right) \mathrm{Cl}$ & $3400-2700 \mathrm{md}$ & $\begin{array}{c}1700 \mathrm{~m}, \\
1640 \mathrm{mb}\end{array}$ & - & $1458 \mathrm{mb}$ & - \\
\hline$\left[\mathrm{Hg}\left(\mathrm{C}_{5} \mathrm{H}_{4} \mathrm{~N}_{5} \mathrm{O}\right)_{2}\right]\left(\mathrm{C}_{5} \mathrm{H}_{6} \mathrm{~N}_{5} \mathrm{O}\right) \mathrm{Cl}$ & $3400-2700 \mathrm{wd}$ & $\begin{array}{l}1710 \mathrm{~m}, \\
1645 \mathrm{md}\end{array}$ & - & $1455 \mathrm{md}$ & - \\
\hline
\end{tabular}

arom $=$ aromatic $; \mathrm{mb}=$ medium broad $; \mathrm{w}=$ weak $; \mathrm{wd}=$ weak and diffused, $\mathrm{m}=$ medium; $\mathrm{sb}=$ strong and broad; $\mathrm{md}=$ medium and diffused.

The stretching vibrations for $\mathrm{H}_{2} \mathrm{O}$ and/or $\mathrm{NH}_{2}$ and $\mathrm{CH}$ groups are merged together resulting into a broad band in the region $3640-2700 \mathrm{~cm}^{-1}$ in all compounds. The broadening of this peak also suggests their involvement in H-bonding. The chromium compound shows a peak of medium intensity at $1720 \mathrm{~cm}^{-1}$ due to $v(>C=O)$ suggesting that the $>\mathrm{C}=\mathrm{O}$ group does not participate in bonding with the metal. This is expected because the chromium compound is a salt comprises $2\left(\mathrm{C}_{5} \mathrm{H}_{6} \mathrm{~N}_{5} \mathrm{O}\right)^{+}$and $\mathrm{Cr}_{2} \mathrm{O}_{7}{ }^{2-}$ ions.

The $v(>\mathrm{C}=\mathrm{O})$ vibration for silver compound appears at $1680 \mathrm{~cm}^{-1}$. The downward shifting of the carbonyl absorption compared to that observed in the free guanine molecule (at $1696 \mathrm{~cm}^{-1}$ ) explains the involvement of the $>\mathrm{C}=\mathrm{O}$ group in bonding with $\operatorname{Ag}(\mathrm{I})$ ion. In fact, $\operatorname{Ag}(\mathrm{I})$ ion in this compound is linearly coordinated to two guaninium ions through carbonyl oxygen, $\mathrm{O}(6)$.

However, both $\mathrm{Cd}(\mathrm{II})$ and $\mathrm{Hg}$ (II) compounds show two peaks in the region of $1710-1640 \mathrm{~cm}^{-1}$. The former may be assigned for free $>\mathrm{C}=\mathrm{O}$ group while the later is due to the metalated $>\mathrm{C}=\mathrm{O}$ group. This observation supports our formulation, because both the compounds contain two types of guanine moiety; the two guaninato anions 
coordinated tetrahedrally to the metal ion through carbonyl oxygen $\mathrm{O}(6)$ and imidazolyl nitrogen $\mathrm{N}(7)$, while the other remains as guaninium chloride in the lattice.

A broad medium band at $1460 \mathrm{~cm}^{-1}$ of silver compound is associated for the vibration of $\mathrm{NO}_{3}{ }^{-}$group. In the spectra of $\mathrm{Cr}(\mathrm{VI})$ and $\mathrm{Ag}(\mathrm{I})$ compounds, a new peak appears at around $1540 \mathrm{~cm}^{-1}$ indicates that the nitrogen of the pyrimidine ring $\mathrm{N}(3)$ is protonated i.e. $\mathrm{N}(3)-\mathrm{H}^{+}$. Similar observation is reported earlier in the case of (HThiamine) $\left(\mathrm{MCl}_{4}\right) \cdot \mathrm{H}_{2} \mathrm{O}$ where $\mathrm{M}=\mathrm{Co}(\mathrm{II}), \mathrm{Cu}(\mathrm{II}), \mathrm{Zn}(\mathrm{II}), \mathrm{Cd}(\mathrm{II})$, and $\mathrm{Hg}(\mathrm{II})$. On the other hand, both $\mathrm{Cd}(\mathrm{II})$ and $\mathrm{Hg}$ (II) compounds show a broad peak at about 1458 and $1455 \mathrm{~cm}^{-1}$ respectively. In comparison with the spectrum of free guanine molecule it can be suggested that this peak may arises due to $v\left(C-\mathrm{N}^{-}\right)$, only when imidazole ring nitrogen $\mathrm{N}(9)$ of guanine is deprotonated.

UV-Vis spectral analyses: The electronic spectral data of the studied metal-guanine compounds in the UV/Vis region are tabulated in Table 3. The bands at shorter wavelengths are resulted from the $\pi \rightarrow \pi^{*}$ and $\mathrm{n} \rightarrow \pi^{*}$ electronic transitions, characteristic spectral properties of heteroaromatic molecule ${ }^{17}$.

Table 3. Data for electronic spectral analyses of metal-guanine compounds.

\begin{tabular}{|l|l|}
\hline \multicolumn{1}{|c|}{ Compound } & Wavelength, $\lambda$ nm \\
\hline$\left(\mathrm{C}_{5} \mathrm{H}_{6} \mathrm{~N}_{5} \mathrm{O}\right)_{2}\left(\mathrm{Cr}_{2} \mathrm{O}_{7}\right) \cdot \mathrm{H}_{2} \mathrm{O}$ & $245.4,275.0,350.0,812.0$ \\
\hline$\left[\mathrm{Ag}\left\{\left(\mathrm{C}_{5} \mathrm{H}_{6} \mathrm{~N}_{5} \mathrm{O}\right)\left(\mathrm{NO}_{3}\right)\right\}_{2}\right]\left(\mathrm{C}_{5} \mathrm{H}_{6} \mathrm{~N}_{5} \mathrm{O}\right)\left(\mathrm{NO}_{3}\right)_{2}$ & $216.0,246.0,271.0$ \\
\hline$\left[\mathrm{Cd}\left(\mathrm{C}_{5} \mathrm{H}_{4} \mathrm{~N}_{5} \mathrm{O}\right)_{2}\right]\left(\mathrm{C}_{5} \mathrm{H}_{6} \mathrm{~N}_{5} \mathrm{O}\right) \mathrm{Cl}$ & $246.0,275.0$ \\
\hline$\left[\mathrm{Hg}\left(\mathrm{C}_{5} \mathrm{H}_{4} \mathrm{~N}_{5} \mathrm{O}\right)_{2}\right]\left(\mathrm{C}_{5} \mathrm{H}_{6} \mathrm{~N}_{5} \mathrm{O}\right) \mathrm{Cl}$ & $246.2,276.0$ \\
\hline
\end{tabular}

The chromium compound shows an absorption band at around $812.0 \mathrm{~nm}$. This observation possibly attributes to the charge transfer electronic transition; excitation of the electrons from the $\sigma$ orbitals originating from the $\mathrm{O}^{2-}$ ligands to the d orbitals of $\mathrm{Cr}(\mathrm{VI})$.

Magnetic measurement: Magnetic susceptibilities of the compounds were measured and the results are summarized in Table 4.

Table 4. Data for mass susceptibilities of metal-guanine compounds under study at $32^{\circ} \mathrm{C}$.

\begin{tabular}{|l|c|c|c|c|c|c|}
\hline \multicolumn{1}{|c|}{ Compound } & $\mathrm{C}_{\text {Bal }}$ & $1, \mathrm{~cm}$ & $\mathrm{~m}, \mathrm{~g}$ & $\mathrm{R}$ & $\mathrm{R}_{\mathrm{o}}$ & $\chi_{\mathrm{g}}$, C.G.S. unit \\
\hline$\left(\mathrm{C}_{5} \mathrm{H}_{6} \mathrm{~N}_{5} \mathrm{O}\right)_{2}\left(\mathrm{Cr}_{2} \mathrm{O}_{7}\right) \cdot \mathrm{H}_{2} \mathrm{O}$ & 1.0230 & 1.9 & 0.0830 & -38 & -33 & $-11.7 \times 10^{-8}$ \\
\hline $\begin{array}{l}{\left[\mathrm{Ag}\left\{\left(\mathrm{C}_{5} \mathrm{H}_{6} \mathrm{~N}_{5} \mathrm{O}\right)\left(\mathrm{NO}_{3}\right)\right\}_{2}\right]} \\
\left(\mathrm{C}_{5} \mathrm{H}_{6} \mathrm{~N}_{5} \mathrm{O}\right)\left(\mathrm{NO}_{3}\right)_{2}\end{array}$ & 1.0235 & 1.9 & 0.1985 & -69 & -33 & $-35.2 \times 10^{-8}$ \\
\hline$\left[\mathrm{Cd}\left(\mathrm{C}_{5} \mathrm{H}_{4} \mathrm{~N}_{5} \mathrm{O}\right)_{2}\right]\left(\mathrm{C}_{5} \mathrm{H}_{6} \mathrm{~N}_{5} \mathrm{O}\right) \mathrm{Cl}$ & 1.0158 & 1.8 & 0.0620 & -46 & -32 & $-41.2 \times 10^{-8}$ \\
\hline
\end{tabular}




\begin{tabular}{|l|l|l|l|l|l|l|}
\hline$\left[\mathrm{Hg}\left(\mathrm{C}_{5} \mathrm{H}_{4} \mathrm{~N}_{5} \mathrm{O}\right)_{2}\right]\left(\mathrm{C}_{5} \mathrm{H}_{6} \mathrm{~N}_{5} \mathrm{O}\right) \mathrm{Cl}$ & 1.0096 & 2.1 & 0.0928 & -49 & -32 & $-38.8 \times 10^{-8}$ \\
\hline
\end{tabular}

The magnetic susceptibility of all compounds is negative suggesting that they are repelled by the applied magnetic field. The compounds are therefore diamagnetic.

Thermal analyses: A combined graphical representation of the quasi-static thermogravimetric analysis of $\mathrm{Cr}(\mathrm{VI}), \mathrm{Ag}(\mathrm{I}), \mathrm{Cd}(\mathrm{II})$ and $\mathrm{Hg}(\mathrm{II})$ compounds is depicted in Fig. 1.

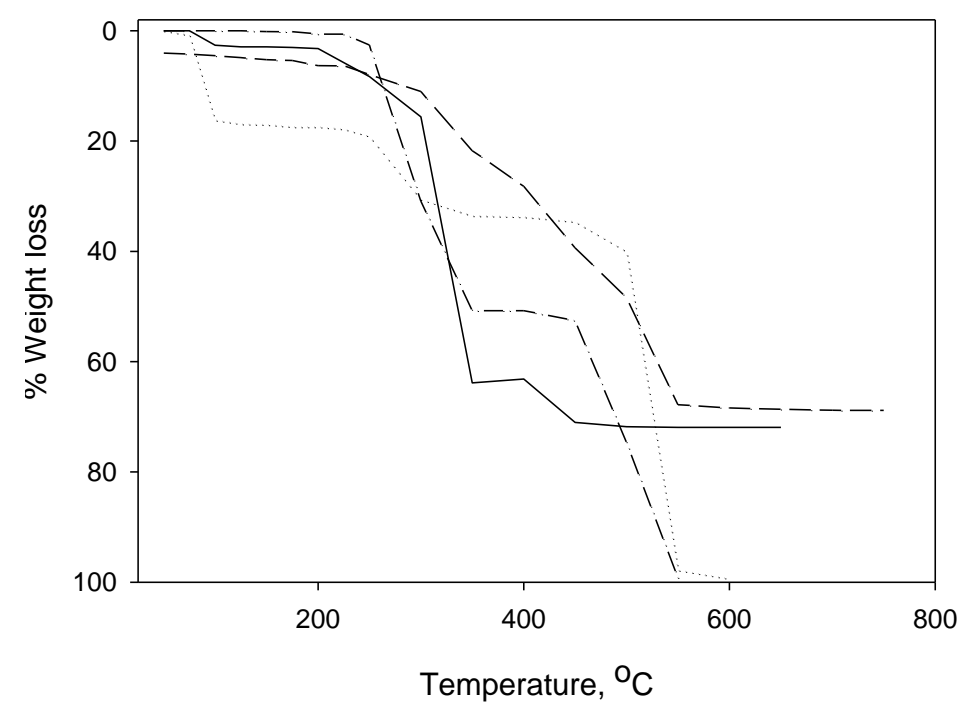

Fig. 1. QSTG curves of the Cr-(solid line), Ag-(dash line), Cd-(dotted) and Hg-guanine (dash-dotted line) compounds.

The dichromate compound loses its weight at relatively low temperature indicating the presence of lattice water in the compound (observed wt. loss $3.22 \%$ and calculated wt. loss $3.34 \%$ ). The decomposition and expulsion of organic ligands occur at high temperature leading to the ultimate production of $\mathrm{Cr}_{2} \mathrm{O}_{3}$ (greenish black, observed wt. $28.89 \%$ and calculated wt. $29.22 \%$ ).

The thermal decomposition $\operatorname{Ag}(\mathrm{I})$ compound starts slowly at $50^{\circ} \mathrm{C}$, and about $6.30 \%$ of total weight loss is registered up to $225^{\circ} \mathrm{C}$. It corresponds to the loss of one $\mathrm{NO}_{3}{ }^{-}$ (calculated wt. $7.65 \%$ ) as $\mathrm{NO}_{2}$. After that the decomposition process is nearly continuous and the residue left at $550^{\circ} \mathrm{C}$ is identified as $\mathrm{Ag}_{2} \mathrm{O}$ (dark ash, observed wt. $32.19 \%$ and calculated wt. $28.63 \%$ ).

The $\mathrm{Cd}(\mathrm{II})$ compound also starts decomposition at low temperature and it suffers a weight loss of $16.22 \%$ within $50-100^{\circ} \mathrm{C}$. Further decomposition occurs in several steps and the sample wholly sublimes off at $600^{\circ} \mathrm{C}$. 
The $\mathrm{Hg}$ (II) compound exhibits thermal stability up to $125^{\circ} \mathrm{C}$, and up to $250^{\circ} \mathrm{C}$ about $2.62 \%$ weight loss is observed. Above this temperature, the decomposition process is rapid and $50.76 \%$ of its total weight loss is recorded up to the temperature $350^{\circ} \mathrm{C}$. The next stage of decomposition is very sharp and no residue is left beyond $550^{\circ} \mathrm{C}$.

Compositional analysis: The absorbance of a series of guanine-potassium dichromate mixtures continuously varying their molar ratios were measured by keeping the total mole in the mixtures constant. The absorbance of the solutions was measured at $440.0 \mathrm{~nm}\left(\lambda_{\max }\right.$ of $\mathrm{K}_{2} \mathrm{Cr}_{2} \mathrm{O}_{7}$ ). The projected composition of the studied compound is (Hguanine): $\left(\mathrm{Cr}_{2} \mathrm{O}_{7}{ }^{2-}\right)=4: 1$. However, quantitative estimation of its $\mathrm{Cr}_{2} \mathrm{O}_{7}{ }^{2-}$ content confirms that the empirical formula of the solid compound is 2(Hguanine): $\left(\mathrm{Cr}_{2} \mathrm{O}_{7}{ }^{2-}\right)$. The anomaly can be explained by the fact that as the solution is dilute, so it may contain a significant amount of $\mathrm{CrO}_{4}{ }^{2-}$ ions in addition to $\mathrm{Cr}_{2} \mathrm{O}_{7}{ }^{2-}\left(2 \mathrm{CrO}_{4}{ }^{2-} \equiv \mathrm{Cr}_{2} \mathrm{O}_{7}{ }^{2-}\right.$ ion). Thus the resultant composition assumes 4(Hguanine): $2\left(\mathrm{CrO}_{4}^{2-}\right)$, which is effectively equal to 4(Hguanine): $\left(\mathrm{Cr}_{2} \mathrm{O}_{7}{ }^{2-}\right)$. However, the compound 4(Hguanine): $\left(\mathrm{Cr}_{2} \mathrm{O}_{7}{ }^{2-}\right)$ is not chemically neutral and cannot be isolated in solid form. From the principle of neutrality and the product obtained from the reaction of protonated guanine and $\mathrm{Cr}_{2} \mathrm{O}_{7}{ }^{2-}$ can be formulated as (Hguanine $)_{2}\left(\mathrm{Cr}_{2} \mathrm{O}_{7}^{2-}\right)$, agrees well with $\mathrm{Cr}_{2} \mathrm{O}_{7}^{2-}$ content estimated in the compound.

\section{Conclusion}

Reactions of guanine with metal ions ( $\mathrm{Cr}(\mathrm{VI}), \mathrm{Ag}(\mathrm{I}), \mathrm{Cd}(\mathrm{II})$ and $\mathrm{Hg}(\mathrm{II}))$ gave binary metal-guanine compounds. On the basis of their metal and chloride contents the compounds are formulated as $\left(\mathrm{C}_{5} \mathrm{H}_{6} \mathrm{~N}_{5} \mathrm{O}\right)_{2}\left(\mathrm{Cr}_{2} \mathrm{O}_{7}\right) \cdot \mathrm{H}_{2} \mathrm{O}$, $\left[\mathrm{Ag}\left\{\left(\mathrm{C}_{5} \mathrm{H}_{6} \mathrm{~N}_{5} \mathrm{O}\right)\left(\mathrm{NO}_{3}\right)\right\}_{2}\right]$ $\left(\mathrm{C}_{5} \mathrm{H}_{6} \mathrm{~N}_{5} \mathrm{O}\right)\left(\mathrm{NO}_{3}\right)_{2}, \quad\left[\left(\mathrm{C}_{5} \mathrm{H}_{4} \mathrm{~N}_{5} \mathrm{O}\right)_{2} \mathrm{Cd}\right]\left(\mathrm{C}_{5} \mathrm{H}_{6} \mathrm{~N}_{5} \mathrm{O}\right) \mathrm{Cl}$ and $\left[\left(\mathrm{C}_{5} \mathrm{H}_{4} \mathrm{~N}_{5} \mathrm{O}\right)_{2} \mathrm{Hg}\right]\left(\mathrm{C}_{5} \mathrm{H}_{6} \mathrm{~N}_{5} \mathrm{O}\right) \mathrm{Cl}$. Their physico-chemical properties are also supported the revealed formula. The probable geometry of the compounds are shown below:

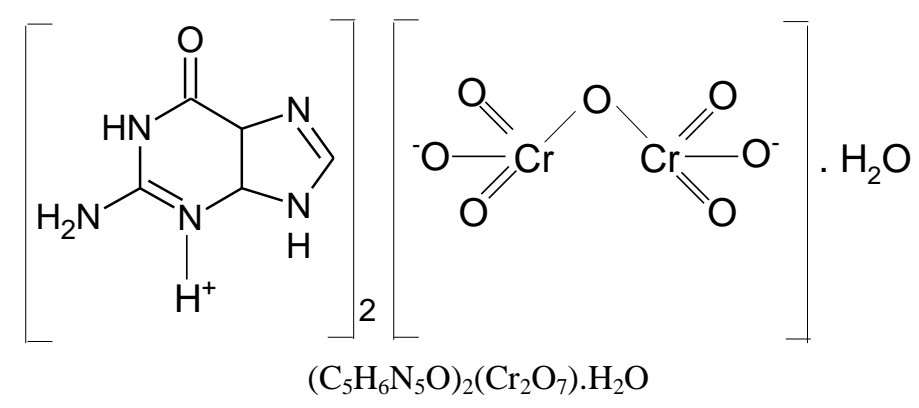




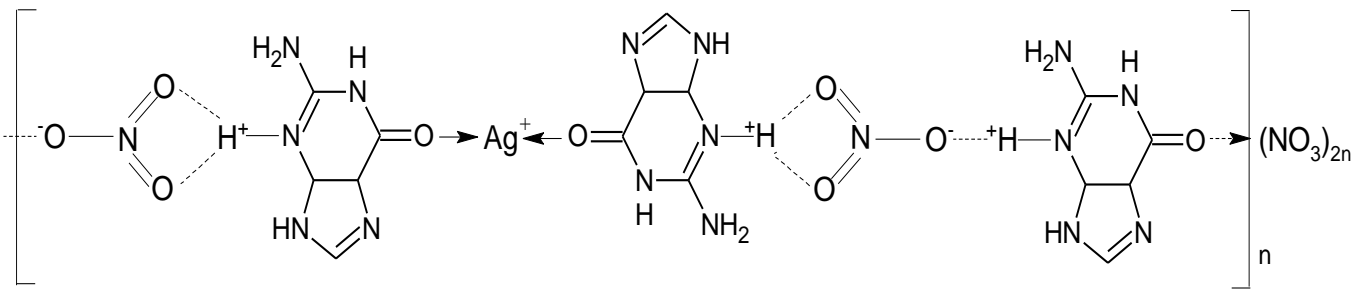

$\left[\mathrm{Ag}\left\{\left(\mathrm{C}_{5} \mathrm{H}_{6} \mathrm{~N}_{5} \mathrm{O}\right)\left(\mathrm{NO}_{3}\right)\right\}_{2}\right]\left(\mathrm{C}_{5} \mathrm{H}_{6} \mathrm{~N}_{5} \mathrm{O}\right)\left(\mathrm{NO}_{3}\right)_{2}$

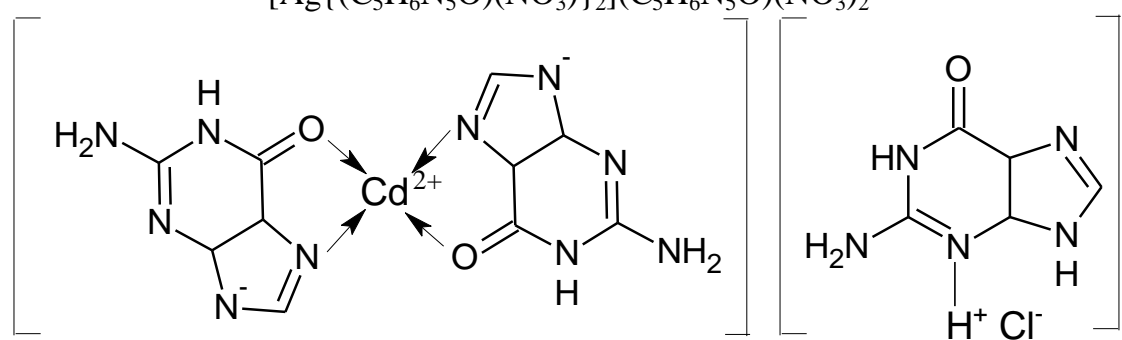

$\left[\left(\mathrm{C}_{5} \mathrm{H}_{4} \mathrm{~N}_{5} \mathrm{O}\right)_{2} \mathrm{Cd}\right]\left(\mathrm{C}_{5} \mathrm{H}_{6} \mathrm{~N}_{5} \mathrm{O}\right) \mathrm{Cl}$

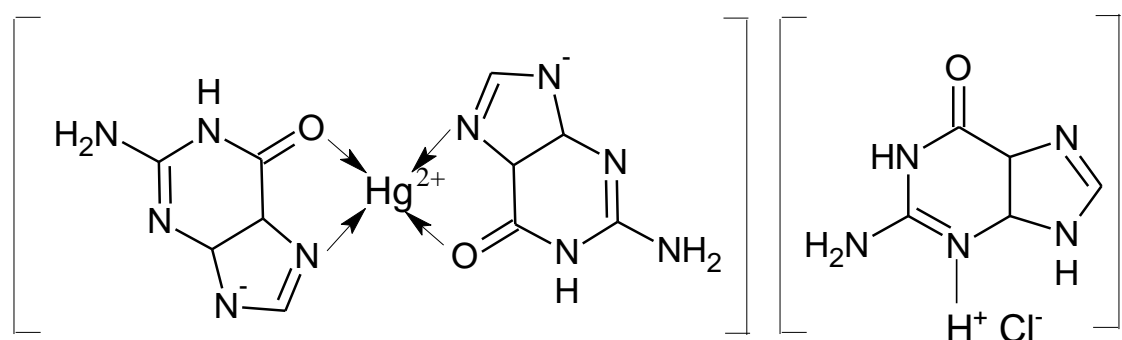

$\left[\left(\mathrm{C}_{5} \mathrm{H}_{4} \mathrm{~N}_{5} \mathrm{O}\right)_{2} \mathrm{Hg}\right]\left(\mathrm{C}_{5} \mathrm{H}_{6} \mathrm{~N}_{5} \mathrm{O}\right) \mathrm{Cl}$

\section{Acknowledgement}

The authors are grateful to University of Dhaka for their financial support to carry out the present work.

\section{References}

1. P. Kamalakannan and D. Venkappayya, J. Inorg. Biochem., 2002, 21, 22.

2. M. S. Islam, M. A. Farooque, M. A. K. Bodruddoza, M. A. Mosaddik and M. S. Alam, J. Biol. Sci., 2002, 2, 797.

3. C. Sultana, M. A. A. Rahman, M. A. A. Al-Bari, M. L. A. Banu, M. S. Islam, N. A. Khatune and G. Sadik, Pak. J. Biol. Sci., 2003, 6, 525.

4. Y. S. Rho, S. A. Kim, J. C. Jung, C. C. Shin and S. G. Chang, Int. J. Oncol., 2002, 20, 929. 
5. E. M. Treshchalina, A. L. Konovalova, M. A. Presnov, L. F. Chapurina and N. I. Belichuk, Dokl. Akad. Nauk., 1979, 248, 1273.

6. L. R. Kelland, C. F. Barnard, K. J. Mellish and M. Jones, Cancer. Res., 1994, 54, 5618.

7. V. M. Amirkhanov, E. A. Bundya, V. A. Trush, V. A. Ovchynnikov and V. N. Zaitsev, " $5^{\text {th }}$ International Symposium on Applied Bioinorganic Chemistry”, Corfu. Greece, 1999, p 13.

8. D. B. Brown, A. R. Khokhar, M. P. Hacker, L. Lokys, J. H. Burchenal, R. A. Newman, J. J. McCormack and D. Frost, J. Med. Chem., 1982, 25, 952.

9. C. K. Mirabelli, D. T. Hill, L. F. Faucette, F. L. McCabe, G. R. Girard, D. B. Bryan, B. M. Sutton, J. O. Bartus, S. T. Crooke and R. K. Johnson, J. Med. Chem., 1987, 30, 2181.

10. M. A. Aras, H. Hara, K. A. Hartnett, K. Kandler and E. Aizenman, J. Neurochem., 2009, 110, 106.

11. A. Romerosa, J, Suarez-Varela, M. A. Hidalgo, J. C. Avila-Roson and E. Colacio, Inorg. Chem., 1997, 36, 3784.

12. J. Reedijk, A. M. Fichtinger-Shepman, A. T. van Oosterom and P. Putte, Struct. Bonding, 1987, 67, 53.

13. B. Lippert, Prog. Inorg. Chem., 1989, 37, 1.

14. B. Rogenberg, L. Van Camp, J. E. Trosko and V. H. Mansour, Nature, 1969, 222, 385.

15. L. G. Marzilli and T. J. Kistenmacher, Acc. Chem. Res., 1977, 10, 146.

16. T. A. Connors and J. J. Roberts, "Platinum Coordination Complexes in Cancer Chemotheraphy", Springer-Verlag, New York, 1977.

17. D. L. Pavia, G. M. Lampman and G. S. Kirz, "Introduction to Spectroscopy", (3 ${ }^{\text {rd }}$ edition), Thomson Learners Inc., New York, 2001, p 360. 